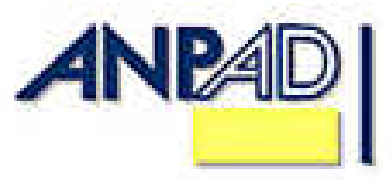

\title{
Barriers to the Accomplishment of a Subsidiary's Strategic Role: How Location and Corporate Networks Influence Subsidiary Performance
} permitido citar parte de artigos sem autorização prévia desde que seja identificada a fonte. 


\title{
Resumo
}

Este trabalho apresenta a evolução da filial de uma multinacional localizada em um país emergente, e tem como objetivo descobrir os obstáculos enfrentados durante evolução da realização da função estratégica. Ao longo de um estudo histórico, voltando 40 anos atrás, o jornal descreve marcos na evolução e destaca os obstáculos enfrentados para o desenvolvimento e aplicação de recursos, sejam eles vindos dos HQ's ou do processo de incorporação da filial. O resultado da pesquisa aponta os obstáculos encontrados pelas filiais ao cumprir o seu papel e mandatos a fim de alcançar internacionalização e as tipologias de evolução que emergem da interação entre as barreiras locais e empresariais.

Palavras-chave: evolução da filial; funções estratégicas; capacidade da filial; multinacionais.

\begin{abstract}
This paper presents the evolution of a multinational's subsidiary, which is located in an emerging country, and aims to uncover barriers encountered during the evolution of the accomplishment of its intended strategic role. Throughout a historical study that goes back 40 years, the paper depicts milestones in the subsidiary's evolution and highlights barriers encountered to developing and deploying capabilities, whether they are transferred from HQ's or emerge from the subsidiary's embedding process. The results of this research point out the barriers a subsidiary faces while accomplishing its role and duties towards the ends of internationalization and evolution typologies that emerge from the interaction between local and corporate barriers.
\end{abstract}

Key words: subsidiary evolution; strategic roles; subsidiary capabilities; multinationals. 


\section{Introduction}

Traditionally, the study of the internationalization of a firm's activities finishes once Foreign Direct Investment (FDI) occurs. However, we believe that success or failure in every attempt at internationalization depends not only on activities carried out during the establishment of foreign subsidiaries but also on post-FDI activities; therefore, attention should be paid to the subsidiaries' evolution rather than merely to the localization process in which strategic intentions and measures are put in place.

In theory, if the localization process is properly planned and concluded, subsidiaries have a greater chance of succeeding in foreign markets. Nonetheless, some subsidiaries face diverse barriers rendering them unable to accomplish their strategic role. What is meant by barriers are all difficulties in a subsidiary's business environment that cannot be easily overcome through corporate knowledge, even though the subsidiary in question went through a proper localization process where corporate coordination and control mechanisms were put in place. Coordination and control mechanisms are defined as those processes and procedures to be adhered to by subsidiary managers in order to replicate corporate knowledge.

Some attempts have been made to focus research more on subsidiaries. For example, while discussing multinationals' (MNE) coordination mechanisms, researchers have highlighted that companies not only allocate resources and transfer technologies but also benefit from the knowledge collected from every node in the network (Casson, Dark, \& Gulamhussen, 2009; Jenkins \& Tallman, 2010; Nachum, Zaheer, \& Gross, 2008). The importance of distinguishing between configuration and coordination activities throughout the internationalization process has also been stated (Beugelsdijk, Pedersen, \& Petersen, 2009; Cerrato, 2006; Li \& Rugman, 2007). Due to this, international business studies (IB) have concentrated their efforts on discussing what are the most suitable coordination mechanisms that allow a MNC to benefit better from foreign subsidiaries; such as the research of (Criscuolo \& Narula, 2007; Maritan, Brush, \& Karnani, 2004; Reger, 2004). Meanwhile, international manufacturing studies (IM) tend to concentrate on what configurations enable effective execution, as in the research of (Ferdows, 1997; Luo \& Zhao, 2004; Shi \& Gregory, 1998; Vereecke \& Dierdonck, 2002). Further research about how subsidiaries collect knowledge states that subsidiaries' linkages and the linkage density are very important in regards to performance and influence within the corporate network (Almeida \& Phene, 2004; Luo \& Zhao, 2004). This concept has given rise to the term embeddedness, defined as the number of exchange relationships between the subsidiary and other entities in and out of the corporate network from which the subsidiary is able to collect potentially commercially exploitable knowledge (Almeida \& Phene, 2004; Andersson, Forsgren, \& Holm, 2001; Clark \& Almond, 2004; Garcia-Pont, Canales, \& Noboa, 2009; Holm, Malmberg, \& Sölvell, 2003; McDonald, Warhurst, \& Allen, 2008).

We believe that the study of barriers to the evolution of subsidiaries is an important research topic because it could not only help managers to foresee and prevent evolutionary constraints but also drive international business studies (IB) to focus on and recognize subsidiary evolution as a key element to success. Another important issue is that although current research has focused on how PostFDI activities come as a consequence of previous internationalization efforts, the idea that they are a continuation of the internationalization process has yet to emerge. This paper claims Post-FDI activities to be a further stage in the maturity of the relationship between a parent company and their subsidiaries, and also an extension of the internationalization process. Therefore, this paper aims to ascertain how barriers to subsidiaries' evolution are one of the main characteristics of its evolution and also to establish which roles plants and subsidiaries are able to play within their networks, rather than merely the traditional view of what the networks pursue through the plants and subsidiaries. 


\section{Literature about Strategic Roles of Subsidiaries, Research Question, Gaps \& Propositions}

Some research (Narula \& Dunning, 2000) classifies FDI motives as: resource seeking, market seeking and efficiency/strategy seeking. Hence, forces and motives combined with companies' strategy and the attractiveness of location constitute a complex mechanism for explaining what it is that MNEs pursue through their subsidiaries. Lall (2002), at his end, define FDI benefits based on proprietary assets (ownership assets) and non-proprietary assets that can be obtained from the market. In consequence, if internationalization explains the resource allocation drivers in foreign countries, then localization should discuss not only the way companies establish and transfer knowledge and technology to their subsidiaries but also how the subsidiary evolves via the development of its capabilities. Once a foreign subsidiary has been set up to play a specific role within a corporate network, coordination between headquarters and the subsidiary is needed to ensure that the corporation gets the best results from that specific node.

It has been stated that the difference in power between foreign business units relies on profit contribution, distance to heartquarters (HQs) and especially the control of critical linkages (Birkinshaw, 1995; Gammelgaard, 2009; Ghoshal \& Bartlett, 1990; Kang \& Li, 2009; Marin \& Verdier, 2009). By controlling these linkages, subsidiaries can influence the assignment of orders from HQ's and engage in further functional and geographical responsibilities (Birkinshaw, 1996; Cantwell \& Mudambi, 2005; Eckert \& Rossmeissl, 2007). However if this were absolutely true, subsidiaries' success would be limited to only those few targeting growing markets that were managed solely by expatriates and having control of political and financial sources. In contrast, it is possible to see disparities in subsidiaries' performance even within healthy organizations or those operating in frugal geographical regions; many of these subsidiaries have failed to accomplish their intended strategic roles and currently remain in their locations. In consequence, our research question is: What are the barriers to the accomplishment of subsidiaries' strategic roles that would keep them from being competitive, not only in their locality, but also across their corporate networks?

Literature about subsidiaries'/plants' strategic roles shows two research strands: authors concerned about the role subsidiaries play based upon type of interaction and flows within the network, and those interested in the role they play based upon characteristics of their location and available knowledge.

Emphasizing the importance of coordination mechanisms, Jarillo and Martínez (1990) discuss the role that subsidiaries play in terms of the degree of coordination and localization of companies' activities. Therefore a receptive subsidiary would carry out activities needing a high degree of integration and a low degree of localization; an autonomous subsidiary would perform activities with a high degree of localization but a low degree of integration, while an active subsidiary would need a high degree of both. It has been stated (Tsai, Yu, \& Lee, 2006) that cultural distance between HQs and Subsidiaries impacts on subsidiaries' perceived satisfaction of their efforts. Three different roles were established: Respective Subsidiaries (low local responsiveness but highly integrated), Autonomous Subsidiaries (high local responsiveness but low integration) and Active Subsidiaries (highly integrated and high local responsiveness). In a similar sense, (Birkinshaw, 1995) defines subsidiary roles based on the effect coordination mechanisms have on subsidiary responsibility as: a local implementer if it is adopting HQ's technology, a specialized contributor if it has significant expertise in a specific function; and a world mandate if it has extended responsibility, geographically speaking. While analyzing the sources of funding accessed by the R\&D labs of foreign multinationals, Papanastassiou and Pearce (2005) also found a correspondence between coordination mechanisms and strategic roles, and using this information defined four roles R\&D labs play: SL1 to support local production operations by assisting in the adaptation of the products to be produced or processes to be used; LIL to develop a distinctive new product that it will produce for its markets; SL2 to support non-UK production operations of the MNE by advising on the adaptation of the products to be produced or processes to be used; and IIL to generate the MNE's core technology. Concerning 
coordination mechanisms but based on network flows, Gupta and Govindarajan (1991) conceptualized subsidiaries' strategic roles in terms of high and low levels of knowledge outflow and inflow: the Global Innovator serves as the fountainhead of knowledge for other units; the Integrated Player role implies a responsibility for creating knowledge that can be utilized by other subsidiaries; the Local Innovator role implies that the subsidiary has almost complete local responsibility for the creation of relevant know-how in all key functional areas; and the Implementor role is one where the subsidiary engages in little knowledge creation of its own and relies heavily on knowledge inflows from sister subsidiaries. Vereecke and Dierdonck (2002) expand upon the inter-organizational flows described by Ghoshal and Bartlett, (1990) and, based upon the degree of centrality, recorded communication, innovation and people movements in a pool of manufacturing plants, defined a new network plant typology: the isolated plant, the blue-print plant, the host plant, and the glue for the network plant. The commonality of the literature mentioned above is that they explain subsidiaries' strategic roles based on MNEs' coordination mechanisms. However, they do consider these coordination mechanisms equally established and fair across the entire organization, which constitutes our first research gap, and enables us to state our first proposition:

Proposition 1: Corporate coordination mechanisms are a potential source of barriers to subsidiaries' accomplishing their strategic roles.

On the other hand, researchers interested in the role subsidiaries play based on characteristics of their locations and knowledge available state the importance of location competence for internationalization drivers: manufacturing cost, access to skills and knowledge, and proximity to market. Ferdows (1997) states six strategic roles of factories: offshore, source, outpost, leader, server and contributor. Location competence is the newly introduced dimension and here subsidiary roles would depend not only on corporate coordination mechanisms but also on location competence. Subsequent research about inter/intra organizational linkages proposed by Bartlett and Ghoshal (1987) evolved the concept of subsidiary embeddedness, defined as the subsidiary's sum of total interdependences as a consequence of its position in a business network. Andersson, Forsgren and Holm (2002) argue that the stronger the technical and business embeddedness of a subsidiary, the better the subsidiary's market performance and its corporate influence (Andersson, Forsgren, \& Holm, 2000, 2001; Andersson, Forsgren, \& Pedersen, 1999; Andersson et al., 2002).

This is an important finding since it radically changes the concept from the previously accepted belief that corporate knowledge and technology flows from HQ's to subsidiaries, to the concept that knowledge can be created, codified and packaged for commercial exploitation and deployed corporately from subsidiaries. This is a tremendous upgrading of subsidiaries' roles by naming them centers of excellence. The literature mentioned above considers subsidiaries' locations as an important booster for subsidiary performance; however all these studies are based on what MNEs can get from the location and not on what the location can offer to them, which constitutes our second research gap and enables us to state our second proposition:

Proposition 2: Location competence is a potential source of barriers to subsidiaries' accomplishing their strategic role.

\section{Research Method}

\section{Research background}

The international community has, since the late 1980's, reported an increase in Foreign Direct Investment (FDI), with developing nations featuring significantly in the total (United Nations Conference on Trade and Development [UNCTAD], 2010). Countries attract FDI flow unevenly and according to their potential, based on inherent advantages due to location and on created competitive advantages (Davis \& Meyer, 2004; Falck \& Heblich, 2008; Talay \& Cavusgil, 2009), such as market 
size, strategic location, the country's resources, industrial profile, industrial agglomeration and synergy, and industrial policy, among others. Within developing nations, those with rich natural resources, such as Mexico and Saudi Arabia, used to be at the top of the list but a change has been reported in the FDI flow rationale from seeking locations with inherent advantages to locations with created advantages (Ozawa \& Castello, 2001; Peneder, 2002) resulting in the emergence of important manufacturing-base countries such as Singapore and Malaysia as well as large markets like China, India and Brazil. In consequence, and since developing countries are increasingly dependent on FDI inflow, mainly from MNE's, it is important to understand the FDI rationale as well as the potential roles MNE subsidiaries are able to play depending on the geographical extent of their mandates (Birkinshaw, 1995), goals pursued by HQ's (Ferdows, 1997), how excellent subsidiary capabilities are (Khurana \& Talbot, 1998), subsidiary autonomy (Ambos \& Birkinshaw, 2010; Cantwell, Dunning, \& Lundan, 2010) and subsidiaries' ability to adopt, pollinate and create knowledge (Andersson, Forsgren, \& Holm, 1996, 2001; Andersson et al., 2001, 2002). The ultimate goal pursued in this work is to discuss the way MNE's' subsidiaries can benefit not only their corporations but also from the local environment.

\section{Selection of research sample}

This research started with the identification, through exploratory case studies (not reported in this paper), of those factors that have made MNE's subsidiaries in Mexico shift their production plants to more beneficial locations. There were five cases looked at in all before selecting the main case reported in this paper, at three different levels of analysis: country, sector and firm. These cases focused on two different types of industries: apparel and electronic. Company cases were selected due to the impact their divestments had on macro-economic figures and the attention they received from academics and policy makers in Mexico. Table 1 shows challenges that emerged from the exploratory case studies, from which it was possible to draw out potential research questions to be analyzed further through the literature review process. Different results that could be obtained from this process:

1. Find accurate answers in the literature to the questions emerging from exploratory cases that can also explain the phenomenon.

2. Find partial or incomplete answers to the questions emerging from exploratory cases that can partially explain the phenomenon. This would identify theoretical gaps and questions could then be modified accordingly until they derive appropriate research questions.

3. Find no answers to the questions emerging from exploratory cases. Then the research would need to build a theory that either explains the phenomenon or assists in furthering research in this matter. 
Table 1

Summary of Challenges and Resulting Literature Topics

\begin{tabular}{|c|c|c|c|}
\hline Case Study & $\begin{array}{l}\text { Challenges which emerged from } \\
\text { exploratory cases }\end{array}$ & $\begin{array}{l}\text { Questions which } \\
\text { emerged }\end{array}$ & $\begin{array}{l}\text { Literature to } \\
\text { Review }\end{array}$ \\
\hline \multirow{5}{*}{$\begin{array}{l}\text { Economic and } \\
\text { Industrial } \\
\text { evolution in } \\
\text { Mexico }\end{array}$} & $\begin{array}{l}\text { 1. Understand the dynamics of global } \\
\text { competition. }\end{array}$ & \multirow{4}{*}{$\begin{array}{l}\text { 1. How can MNE's } \\
\text { be encouraged to } \\
\text { stay longer in } \\
\text { Mexico? } \\
\text { 2. How can } \\
\text { indigenous industry } \\
\text { be underpinned? }\end{array}$} & $\begin{array}{l}\text { 1. Firm growth } \\
\text { theory }\end{array}$ \\
\hline & \multirow{2}{*}{$\begin{array}{l}\text { 2. Understand the ways technology can be not } \\
\text { only adopted from abroad but also created and } \\
\text { spread across Mexican manufacturers. }\end{array}$} & & $\begin{array}{l}\text { - Definition of } \\
\text { growth }\end{array}$ \\
\hline & & & - Growth \\
\hline & 3. Understand the role of industrial policy in & & mechanism \\
\hline & underpinning indigenous and foreign & 3. How can the & $\begin{array}{l}\text { - Role of } \\
\text { entrepreneurship }\end{array}$ \\
\hline \multirow{3}{*}{$\begin{array}{l}\text { Apparel } \\
\text { Industry in } \\
\text { Mexico }\end{array}$} & \multirow{2}{*}{$\begin{array}{l}\text { 1. Understand the way indigenous } \\
\text { manufacturers can access technology and } \\
\text { novel manufacturing practices. }\end{array}$} & \multirow{5}{*}{$\begin{array}{l}\text { orientation of } \\
\text { products } \\
\text { manufactured in } \\
\text { Mexico be } \\
\text { boosted? } \\
\text { 4. How can } \\
\text { sustainable FDI } \\
\text { inflows be } \\
\text { ensured? }\end{array}$} & $\begin{array}{l}\text { - Role of } \\
\text { technology }\end{array}$ \\
\hline & & & 2. Theory of \\
\hline & 2. Understand the dynamic of international & & Production \\
\hline \multirow{5}{*}{$\begin{array}{l}\text { Sara Lee } \\
\text { divests } \\
\text { operations in } \\
\text { Mexico }\end{array}$} & $\begin{array}{l}\text { JV's and the role of systems integrators. } \\
\text { 1. Understand different costs involved in } \\
\text { producing in foreign countries. }\end{array}$ & & $\begin{array}{l}\text { - Inherent \& created } \\
\text { competitive } \\
\text { advantages }\end{array}$ \\
\hline & 2. Understand drivers that motive such & & - Transactional cost \\
\hline & $\begin{array}{l}\text { companies to operate under Maquiladora } \\
\text { program. }\end{array}$ & & $\begin{array}{l}\text { 3. International } \\
\text { Manufacturing }\end{array}$ \\
\hline & 3. Understand the role of technology in & & studies \\
\hline & firm/location wealth. & & - Network \\
\hline \multirow{6}{*}{$\begin{array}{l}\text { Electronics } \\
\text { Industry in } \\
\text { Mexico }\end{array}$} & 1. Understand the role of research institutions & & configuration \\
\hline & on the development of technology. & & - Plant roles \\
\hline & $\begin{array}{l}\text { 2. Understand the role of industrial policy in } \\
\text { reinforcing the infrastructure of the country. }\end{array}$ & & $\begin{array}{l}\text { 4. International } \\
\text { Business studies }\end{array}$ \\
\hline & $\begin{array}{l}\text { 3. Understand the dynamics of global } \\
\text { competition and its effects on industrial }\end{array}$ & & $\begin{array}{l}\text { - Network } \\
\text { coordination }\end{array}$ \\
\hline & organization. & & - Subsidiary \\
\hline & $\begin{array}{l}\text { 4. Understand industrial trends and their effect } \\
\text { on regulatory matters. }\end{array}$ & & management \\
\hline \multirow{2}{*}{$\begin{array}{l}\text { Phillips } \\
\text { transfers } \\
\text { production lines } \\
\text { to China }\end{array}$} & $\begin{array}{l}\text { 1. Understand the way companies get involved } \\
\text { in activities upstream of the supply chain, } \\
\text { including R\&D. }\end{array}$ & & \\
\hline & $\begin{array}{l}\text { 2. Understand 'manufacturing' as the complete } \\
\text { process from the conception of the idea to } \\
\text { placing a product in the client's hands. }\end{array}$ & & \\
\hline
\end{tabular}

Table 2 takes the questions emerging from exploratory cases, compares them with the literature review and suggests four statements that could have a positive impact on such questions. However, there is still a lack of answers for some specific issues that can potentially become theoretical gaps. There are isolated relationships such as:

1. Long-term generation of profit $\rightarrow$ MNE's stay longer.

2. Subsidiary embeddedness $\rightarrow$ benefits to location.

3. Greater investment in subsidiary (knowledge/technology) $\rightarrow$ Greater chances of success. 
Therefore, it is possible to paraphrase the questions emerging from exploratory cases into one more comprehensive one that includes Greater investment (Plant/subsidiary role) with long term generation of profit (benefit to corporation) and with subsidiary embeddedness (benefit to location) $\rightarrow$ How can subsidiaries upgrade their roles to support their corporations and the local economy?

Table 2

Linking literature review \& exploratory cases

\section{Summary of Literature Review}

\begin{tabular}{|c|c|}
\hline Firms' Growth & A: Sustainability growth only through the long-term generation of profit. \\
\hline & $\begin{array}{l}\text { B: Growth depends on companies' perception of: risk/uncertainty acceptance, ambition of } \\
\text { founders, managerial style, functional heterogeneity and entrepreneurial attitude. }\end{array}$ \\
\hline
\end{tabular}

Theory of International Production

International Manufacturing Studies

International Business Studies

C: Companies embark on international production because of market imperfections.

D: Companies transfer a complete package of technology, skills and knowledge.

E: A close cultural distance between companies' home and host country and the incremental commitment boosts internationalization.

F: Plant roles denote what the corporation aims to get from the new site.

G: Through location decisions companies select a new production site, relocate an existing facility and reallocate existing ones; the analysis can be done either in snap-shot or dynamic basis taking in account either a single function or a network approach.

H: Geographical dispersion and learning and thriftiness ability are the manufacturing network's features that shape its multi-domestic or global-coordinated configuration. Network's operational performance depends on network/plant capabilities interaction.

I: Centrifugal/centripetal forces impact on internationalization speed for seeking: resources, market, and efficiency/strategy.

J: Global coordination and national responsiveness is pursued throughout subsidiary roles, in which operational freedom depends on subsidiary influence on network.

K: Subsidiary knowledge through adoption, diffusion and creation levels and intensity depends on its degree of embeddedness.

Linking exploratory cases to literature review

\section{Questions from} exploratory cases

Do answers satisfy question?
1. How can MNE's be encouraged to stay longer in Mexico?

2. How can indigenous industry be underpinned?

3. How can the technological orientation of products manufactured in Mexico be boosted?

4. How can sustainable FDI inflows be ensured?

A: Partially; if profitable, MNE's will stay in Mexico but this is not directly related either to the firm's degree of investment or its creation of wealth.

B: NO; even with a low degree of risk and uncertainty, MNE's will shift their activities.

C: NO; market imperfections appear to be worldwide but MNE's stay just in certain locations.

D: Partially, greater knowledge transferred leads to greater chances to succeed but how can we make this happen? Is HQ's knowledge enough?

E: NO; if that is the case then the process of attracting FDI is slow and very limited.

F: NO; MNE goals are never committed just to a specific site.

G: Partially; the amount of infrastructure encourages FDI but it is not enough since global competition is high.

H: Partially; how can subsidiaries influence network configuration decisions?

I: NO; centrifugal/centripetal forces appear to be worldwide but MNE's stay just in certain locations.

J: Partially; since it does not explain how subsidiaries can drive investments to their plants to improve their position.

K: Partially; since it does not explain the process of embeddedness. 
Table 2 (continued)

\section{Linking exploratory cases to literature review}

Paraphrased Statements that partially answer the questions which emerged from exploratory case studies: Questions - Long term generation of profit.

- As greater knowledge is transferred, the chances of success become greater.

- High level of infrastructure encourages FDI inflows.

- High degree of embeddedness boosts investment.

Remaining lack of answers

- Is firm growth directly related to either the degree of investment or the creation of wealth?

- How is it possible to ensure the transference of knowledge?

- How can subsidiaries influence network configuration decisions?

- How can subsidiaries drive investments to their plants to improve their position?

- How can subsidiaries embed in their business environment?

- How can subsidiaries upgrade their roles to support their corporations and the local economy?

\section{Summary of Subsidiary Evolution}

Table 3 shows the characteristics of the development phases of the subsidiary, marked by milestones of initiation, as well as its future challenges. 
Table 3

Subsidiary Evolution in Brief

\begin{tabular}{|c|c|c|c|c|c|c|c|}
\hline Phase & Milestones & Period & Characteristics & Evolution Drivers & Manufacturing Practices & Business Practices & Future Challenges \\
\hline $\begin{array}{l}\text { Phase I: } \\
\text { Independent } \\
\text { Importer }\end{array}$ & $\begin{array}{l}\text { Exposition } \\
\text { of German } \\
\text { Industry in } \\
\text { Mexico }\end{array}$ & $\begin{array}{c}1935- \\
1949\end{array}$ & $\begin{array}{l}\text { Open market for vehicles such as } \\
\text { Beetle was an important initial } \\
\text { task. } \\
\text { The process of engagement } \\
\text { between the company and } \\
\text { Mexico is an important } \\
\text { characteristic of this stage. }\end{array}$ & $\begin{array}{l}\text { Evolution driver in phase I: exploit } \\
\text { Beetle's characteristics of low cost } \\
\text { and stiff construction. } \\
\text {-Evolution driver within Phase I and } \\
\text { Phase II: high taxes on imported } \\
\text { vehicles; compulsory production of } \\
\text { engines and manufacture of at least } \\
60 \% \text { of cars' components in Mexico. }\end{array}$ & $\begin{array}{l}\text { SKD and CKD mechanisms were } \\
\text { adopted before the automotive } \\
\text { decree of } 1962 \text { in order to reduce } \\
\text { transportation costs. }\end{array}$ & $\begin{array}{l}\text { Sales, distribution and } \\
\text { post-sales services in } \\
\text { main cities such as } \\
\text { Mexico City, Puebla } \\
\text { City and Torreon. } \\
\text { Independent importers } \\
\text { establish a formal } \\
\text { relationship with VW. }\end{array}$ & $\begin{array}{l}\text { 1.Labor issues arise as one } \\
\text { of the key barriers for } \\
\text { reaching the flexibility } \\
\text { needed. Inflexible labour } \\
\text { legislation disables } \\
\text { managers from reducing } \\
\text { working time when market } \\
\text { demand decreases, leading } \\
\text { to workers being laid-off, }\end{array}$ \\
\hline $\begin{array}{l}\text { Phase II: } \\
\text { Localization }\end{array}$ & $\begin{array}{l}\text { A new plant } \\
\text { is built in } \\
\text { Puebla, } \\
\text { Mexico }\end{array}$ & $\begin{array}{c}1964- \\
1970\end{array}$ & $\begin{array}{l}\text { Selection of a location in Mexico } \\
\text { to establish a new plant. } \\
\text { Process of localization of VW's } \\
\text { technology and business } \\
\text { practices. } \\
\text {. Emphasis is given to training. }\end{array}$ & $\begin{array}{l}\text { Evolution driver in Phase II is: } \\
\text { subsidiary managers concentrated on } \\
\text { quickly and accurately adopting } \\
\text { technology and business practices } \\
\text { from HQ's. } \\
\text { Evolution drivers within Phase II and } \\
\text { Phase III are: reduce dependency } \\
\text { from HQ's to run already established } \\
\text { business processes. }\end{array}$ & $\begin{array}{l}\text { SKD and CKD mechanisms were } \\
\text { gradually changed by in-house } \\
\text { production. } \\
\text { The Mexican subsidiary adopted } \\
\text { existing manufacturing technology } \\
\text { in the corporate network. which } \\
\text { was flex-mass production. }\end{array}$ & $\begin{array}{l}\text { A formal relationship } \\
\text { between the Mexican } \\
\text { plant and VW is } \\
\text { established, the } \\
\text { subsidiary develops } \\
\text { local suppliers to } \\
\text { comply with the } \\
\text { national content } \\
\text { exigency. }\end{array}$ & $\begin{array}{l}\text { with a direct impact on } \\
\text { training costs. This is } \\
\text { particularly important for } \\
\text { the subsidiary since it is } \\
\text { immersed in an internal } \\
\text { competition with other } \\
\text { business units to drive } \\
\text { further investment into } \\
\text { their locations. }\end{array}$ \\
\hline $\begin{array}{l}\text { Phase III: } \\
\text { Local } \\
\text { Network } \\
\text { Development }\end{array}$ & $\begin{array}{l}\text { A training } \\
\text { center is } \\
\text { built }\end{array}$ & $\begin{array}{c}1970- \\
1988\end{array}$ & $\begin{array}{l}\text { New vehicles were introduced } \\
\text { and export to the US and Europe } \\
\text { started. } \\
\text { Technological change took place. } \\
\text { Economic instability during this } \\
\text { period impacted deeply on the } \\
\text { national market. }\end{array}$ & $\begin{array}{l}\text { Evolution drivers in Phase III: the } \\
\text { disengagement from HQ's in } \\
\text { operational terms; complying with } \\
\text { exporting mandates. } \\
\text { Evolution drivers within Phase III and } \\
\text { IV: exploit location's advantages such } \\
\text { as trade agreements, manufacturing } \\
\text { costs and strategic position in North } \\
\text { America. }\end{array}$ & $\begin{array}{l}\text { Technological change pushed the } \\
\text { subsidiary's managers to carry out a } \\
\text { supplier development program. } \\
\text { Operational complexity increased. } \\
\text { VW closed down its manufacturing } \\
\text { plant in the US and transferred } \\
\text { manufacturing lines to the Mexican } \\
\text { plant. }\end{array}$ & $\begin{array}{l}\text { Subsidiary starts } \\
\text { developing activities } \\
\text { not related to } \\
\text { manufacturing and } \\
\text { enlarging its base of } \\
\text { suppliers in the } \\
\text { location }\end{array}$ & $\begin{array}{l}\text { 2. The subsidiary is still } \\
\text { limited in two main } \\
\text { capabilities: participation } \\
\text { of local suppliers in } \\
\text { forward sourcing and the } \\
\text { design of the vehicle's hats } \\
\text { for the North American } \\
\text { market. }\end{array}$ \\
\hline $\begin{array}{l}\text { Phase IV: } \\
\text { Internal and } \\
\text { external } \\
\text { embeddedness }\end{array}$ & $\begin{array}{l}\text { Closing } \\
\text { down of } \\
\text { VW plant in } \\
\text { the US }\end{array}$ & $\begin{array}{c}1988- \\
\text { now }\end{array}$ & $\begin{array}{l}\text { Liberalization of the automotive } \\
\text { sector in Mexico. } \\
\text { Faster technological upgrade of } \\
\text { vehicles than is demanded in the } \\
\text { Mexican automotive market. } \\
\text { Specialization of the Mexican } \\
\text { subsidiary to manufacture mid- } \\
\text { size cars. }\end{array}$ & $\begin{array}{l}\text { Build interdependence between the } \\
\text { Mexican subsidiary and different } \\
\text { business entities in and out of the } \\
\text { corporate network. }\end{array}$ & $\begin{array}{l}\text { VWM is appointed as the } \\
\text { manufacturing center for North } \\
\text { American region. } \\
\text { VWM put a special emphasis on } \\
\text { improving its business practices } \\
\text { with local suppliers by reducing } \\
\text { logistics complexity and inventory } \\
\text { along the value chain. }\end{array}$ & $\begin{array}{l}\text { VWM increases its } \\
\text { interdependency with } \\
\text { other business entities }\end{array}$ & \\
\hline $\begin{array}{l}\text { Phase V: } \\
\text { Centre of } \\
\text { excellence }\end{array}$ & $\begin{array}{l}\text { New Beetle } \\
\text { is launched } \\
\text { from } \\
\text { Mexico }\end{array}$ & $\begin{array}{c}1998- \\
\text { Now }\end{array}$ & $\begin{array}{l}\text { New Beetle is produced } \\
\text { exclusively in Mexico. } \\
\text { The subsidiary exports its } \\
\text { manufacturing knowledge about } \\
\text { the A4 production platform. }\end{array}$ & $\begin{array}{l}\text { Adopt and disseminate corporate } \\
\text { knowledge, collect and package } \\
\text { commercially exploitable knowledge. } \\
\text { Coordinate solutions regionally with } \\
\text { other subsidiaries. }\end{array}$ & $\begin{array}{l}\text { Mass customization of subsidiary } \\
\text { vehicles via the modularization of } \\
\text { parts and components. } \\
\text {. Adaptation of company's vehicles } \\
\text { to specific market needs. }\end{array}$ & $\begin{array}{l}\text { Subsidiary coordinates } \\
\text { activities regionally } \\
\text { with US and Canada } \\
\text { subsidiaries }\end{array}$ & \\
\hline
\end{tabular}




\section{Characteristics and Attributes of Subsidiary Evolution}

In this section, the subsidiary's (denoted by VWM acronym) evolution attributes will be depicted similarly to how this was done for the parent company (Salgado, 2008). However, as is expected in any HQ's-subsidiary relationship, most of the subsidiary's activities respond to a corporate strategy rather than isolated decisions made locally. In consequence, the analysis emphasizes barriers to the evolutionary process.

Figure 1 exhibits five main milestones denoting that the subsidiary went through a transformation process:

1. The Beetle exhibition at the 1953 Industrial Fair in Mexico City raised expectations about the possibility of introducing such vehicles to Mexico. Local investors embraced the venture, became exclusive importers and exploited Beetle's market for ten years $\left(\mathbf{M}_{\mathbf{1}}\right)$.

2. Independent importers sold their share to the parent company and the company built a new plant in Puebla City; this was an intense period of training and technology transfer which bore fruit only seven years after establishing the plant $\left(\mathbf{M}_{\mathbf{2}}\right)$.

3. The creation of a training center enabled the subsidiary to reduce its dependency on HQ control and on the use of expatriates. This capability was exploited later on by training Mexican managers for executive positions, leading to the Mexicanization of the subsidiary $\left(\mathbf{M}_{\mathbf{3}}\right)$.

4. The closing down of a sister plant in the US and the transference of its production lines into Mexico enabled the subsidiary to become the manufacturing center for North America and extended its manufacturing capabilities because of the need to comply with different market requirements. This capability was then exploited further and foreign sales reached $82 \%$ of the total sales $\left(\mathbf{M}_{4}\right)$.

Excellent performance by the subsidiary and the promising business environment in the North American region turned the subsidiary into a center of excellence; the parent company chose the subsidiary out of the whole corporate network to launch the new version of the Beetle from Mexico on a worldwide basis. This capability was later exploited by specializing the subsidiary's manufacturing technology on the A4 platform, which has recently been deployed to other subsidiaries ( $\left.\mathbf{M}_{5}\right)$.

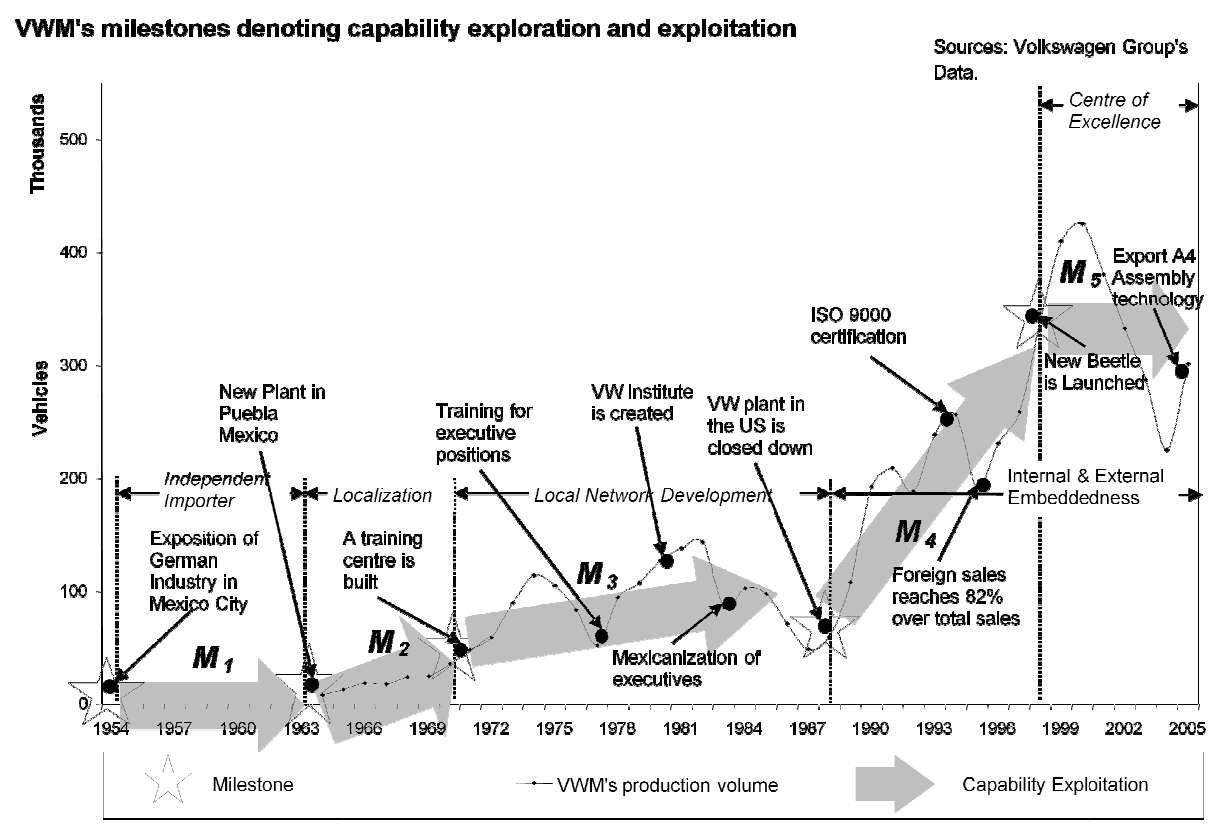

Figure 1. Milestones Denoting Capability Exploration \& Exploitation Along Subsidiary Evolutionary Process. 
After explaining the above examples of capability exploration and exploitation, Table 4 exhibits a detailed list of main milestones as well as their characteristics and associated attributes.

Table 4

\section{From Subsidiary's Milestones to Evolution Attributes Table}

\begin{tabular}{|c|c|c|c|c|}
\hline No. & Phase & Milestone & Characteristic & Attribute \\
\hline 1 & $\begin{array}{l}\text { Phase I: } \\
\text { Independent }\end{array}$ & VW's cars exhibited in Mexico City & $\begin{array}{l}\text { Capability } \\
\text { Exploration }\end{array}$ & $\begin{array}{l}\text { Corporate } \\
\text { Barrier }\end{array}$ \\
\hline 2 & $\begin{array}{l}\text { Importer } \\
(1954-1964)\end{array}$ & $\begin{array}{l}\text { Volkswagen Mexicana is founded as independent } \\
\text { importer }\end{array}$ & $\begin{array}{l}\text { Capability } \\
\text { Exploitation }\end{array}$ & Local Barrier \\
\hline 3 & $(1954-1964)$ & Beetles participate in the Pan-American & $\begin{array}{l}\text { Capability } \\
\text { Exploitation }\end{array}$ & Local Barrier \\
\hline 4 & & JV signed with Chrysler Mexico to assemble Beetle & $\begin{array}{l}\text { Capability } \\
\text { Exploration }\end{array}$ & Local Barrier \\
\hline 5 & & First beetles are assembled in Mexico & $\begin{array}{l}\text { Capability } \\
\text { Exploitation }\end{array}$ & $\begin{array}{l}\text { Corporate } \\
\text { Barrier }\end{array}$ \\
\hline 7 & & $\begin{array}{l}2^{\text {nd }} \text { agreement to assemble Beetle by British Motor } \\
\text { Company }\end{array}$ & $\begin{array}{l}\text { Capability } \\
\text { Exploitation }\end{array}$ & Local Barrier \\
\hline 8 & & $\begin{array}{l}\text { Independent importer (Volkswagen Mexicana) If } \\
\text { so name needs full capitalisation. If not, leave as is } \\
\text { and changes "acquires" to "acquire"] acquires } \\
\text { British Motor Company }\end{array}$ & $\begin{array}{l}\text { Capability } \\
\text { Exploration }\end{array}$ & $\begin{array}{l}\text { Corporate } \\
\text { Barrier }\end{array}$ \\
\hline 9 & & $\begin{array}{l}\text { Investigation into viability of producing Beetles in } \\
\text { Mexico }\end{array}$ & $\begin{array}{l}\text { Capability } \\
\text { Exploration }\end{array}$ & $\begin{array}{l}\text { Corporate } \\
\text { Barrier }\end{array}$ \\
\hline 10 & & $\begin{array}{l}\text { VW buys independent importers' shares and founds } \\
\text { VWM }\end{array}$ & $\begin{array}{l}\text { Capability } \\
\text { Exploitation }\end{array}$ & Local Barrier \\
\hline 11 & $\begin{array}{l}\text { Phase II: } \\
\text { Localization }\end{array}$ & A new plant is built in Puebla, Mexico & $\begin{array}{l}\text { Capability } \\
\text { Exploration }\end{array}$ & Local Barrier \\
\hline 12 & $(1964-1970)$ & Stamping process and production line start & $\begin{array}{l}\text { Capability } \\
\text { Exploitation }\end{array}$ & Local Barrier \\
\hline 13 & & $\begin{array}{l}\text { Another important supplier builds a press shop in } \\
\text { Puebla }\end{array}$ & $\begin{array}{l}\text { Capability } \\
\text { Exploration }\end{array}$ & Local Barrier \\
\hline 14 & & Inauguration of the training center in Puebla & $\begin{array}{l}\text { Capability } \\
\text { Exploitation }\end{array}$ & Local Barrier \\
\hline 15 & & VWM exports its first engines to US and Colombia & $\begin{array}{l}\text { Capability } \\
\text { Exploration }\end{array}$ & $\begin{array}{l}\text { Corporate } \\
\text { Barrier }\end{array}$ \\
\hline 16 & & VWM exports front seat coverings to Germany & $\begin{array}{l}\text { Capability } \\
\text { Exploitation }\end{array}$ & $\begin{array}{l}\text { Corporate } \\
\text { Barrier }\end{array}$ \\
\hline 17 & & $\begin{array}{l}\text { Credit given to local dealers to acquire vehicles and } \\
\text { spare parts }\end{array}$ & $\begin{array}{l}\text { Capability } \\
\text { Exploration }\end{array}$ & Local Barrier \\
\hline
\end{tabular}

Continue 


\section{Table 4 (continued)}

\begin{tabular}{|c|c|c|c|c|}
\hline No. & Phase & Milestone & Characteristic & Attribute \\
\hline 18 & $\begin{array}{l}\text { Phase III: } \\
\text { Local }\end{array}$ & VWM exports cars to Central America & $\begin{array}{l}\text { Capability } \\
\text { Exploitation }\end{array}$ & Local Barrier \\
\hline 19 & $\begin{array}{l}\text { Network } \\
\text { Development }\end{array}$ & Type 2 production starts & $\begin{array}{l}\text { Capability } \\
\text { Exploitation }\end{array}$ & $\begin{array}{l}\text { Corporate } \\
\text { Barrier }\end{array}$ \\
\hline 20 & & New training center, unique in Latin America & $\begin{array}{l}\text { Capability } \\
\text { Exploitation }\end{array}$ & Local Barrier \\
\hline 21 & & The Thing is exported to the US & $\begin{array}{l}\text { Capability } \\
\text { Exploration }\end{array}$ & $\begin{array}{l}\text { Corporate } \\
\text { Barrier }\end{array}$ \\
\hline 22 & & $\begin{array}{l}\text { VW executives promote Brazil and Mexico trade } \\
\text { exchange }\end{array}$ & $\begin{array}{l}\text { Capability } \\
\text { Exploration }\end{array}$ & Local Barrier \\
\hline 23 & & The Brasilia model is launched on Mexican Market & $\begin{array}{l}\text { Capability } \\
\text { Exploitation }\end{array}$ & Local Barrier \\
\hline 24 & & $\begin{array}{l}\text { Mexican workers are sent to Germany for technical } \\
\text { training }\end{array}$ & $\begin{array}{l}\text { Capability } \\
\text { Exploitation }\end{array}$ & Local Barrier \\
\hline 25 & & Outsourcing of seats and harnesses & $\begin{array}{l}\text { Capability } \\
\text { Exploration }\end{array}$ & Local Barrier \\
\hline 26 & & $\begin{array}{l}\text { VWM trains } 35 \text { young engineers for executive } \\
\text { positions }\end{array}$ & $\begin{array}{l}\text { Capability } \\
\text { Exploitation }\end{array}$ & Local Barrier \\
\hline 27 & & Golf A1 (Rabbit) is introduced to the market & $\begin{array}{l}\text { Capability } \\
\text { Exploitation }\end{array}$ & $\begin{array}{l}\text { Corporate } \\
\text { Barrier }\end{array}$ \\
\hline 28 & & VW transfers Beetle's production lines to Mexico & $\begin{array}{l}\text { Capability } \\
\text { Exploitation }\end{array}$ & $\begin{array}{l}\text { Corporate } \\
\text { Barrier }\end{array}$ \\
\hline 29 & & $\begin{array}{l}\text { VWM, VWAG and Banco de Mexico establish a } \\
\text { financing instrument to cover exchange risks }\end{array}$ & $\begin{array}{l}\text { Capability } \\
\text { Exploitation }\end{array}$ & Local Barrier \\
\hline 30 & & $\begin{array}{l}\text { VWM hires } 35 \text { young engineers to be trained as } \\
\text { executives }\end{array}$ & $\begin{array}{l}\text { Capability } \\
\text { Exploitation }\end{array}$ & Local Barrier \\
\hline 31 & & $\begin{array}{l}\text { Project to increase VWM's supplier base to reduce } \\
\text { costs }\end{array}$ & $\begin{array}{l}\text { Capability } \\
\text { Exploitation }\end{array}$ & Local Barrier \\
\hline 32 & & New manufacturing plant in the US (VWofA) & $\begin{array}{l}\text { Capability } \\
\text { Exploration }\end{array}$ & $\begin{array}{l}\text { Corporate } \\
\text { Barrier }\end{array}$ \\
\hline 33 & & $\begin{array}{l}\text { Investment in VWM to increase capacity to } \\
\text { complement VWofA }\end{array}$ & $\begin{array}{l}\text { Capability } \\
\text { Exploitation }\end{array}$ & $\begin{array}{l}\text { Corporate } \\
\text { Barrier }\end{array}$ \\
\hline 34 & & VW Institute is created & $\begin{array}{l}\text { Capability } \\
\text { Exploitation }\end{array}$ & Local Barrier \\
\hline 35 & & VWM starts measuring industrial waste & $\begin{array}{l}\text { Capability } \\
\text { Exploration }\end{array}$ & Local Barrier \\
\hline 36 & & $\begin{array}{l}\text { Project for Mexicanizing the executive level of the } \\
\text { company }\end{array}$ & $\begin{array}{l}\text { Capability } \\
\text { Exploitation }\end{array}$ & Local Barrier \\
\hline 37 & & $\begin{array}{l}\text { Negotiation with VWofA to export A1 vehicles to } \\
\text { the US }\end{array}$ & $\begin{array}{l}\text { Capability } \\
\text { Exploration }\end{array}$ & $\begin{array}{l}\text { Corporate } \\
\text { Barrier }\end{array}$ \\
\hline
\end{tabular}

Continue 
Table 4 (continued)

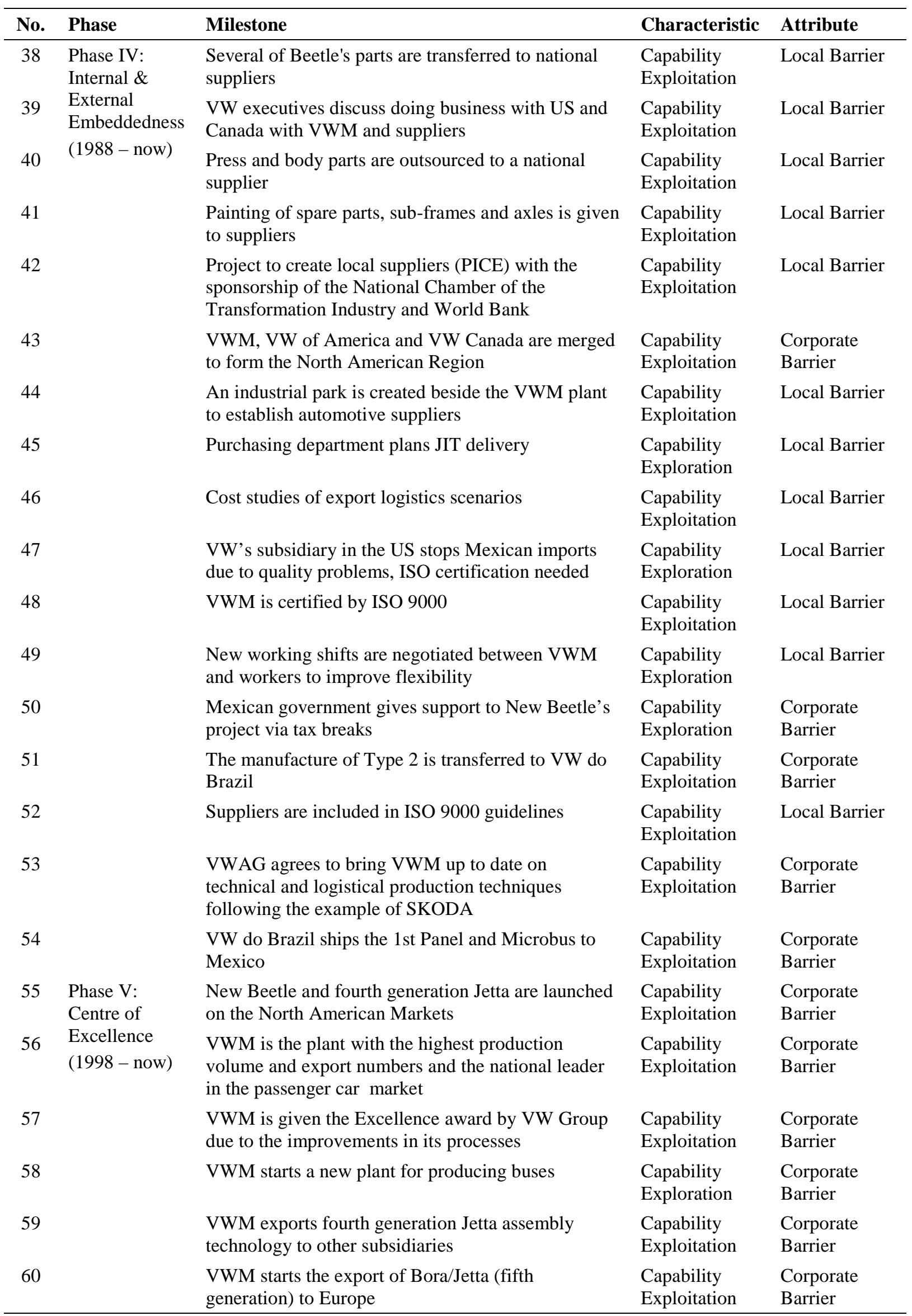


Two characteristics are associated with every milestone:

1. Capability Exploration, which is concerned with those milestones denoting that the subsidiary (or Independent Importer in the initial stage) puts effort into gaining new technology or business practices and incorporates them into the subsidiary's capabilities; therefore, capability exploration would group together all stages of the learning process until the new skill is fully adopted.

2. Capability Exploitation, which is concerned with those milestones denoting that the subsidiary (or independent importers in the initial stage, which was Volkswagen Mexicana) puts effort into deploying an existing capability in the subsidiary's operational region.

However, there are two attributes associated with each milestone that denote the type of barrier the subsidiary must overcome in order to reach a better position either in the market or across the corporate network:

I. The Local (Development) Barrier, which is concerned with those milestones denoting that the business environment constrains the development of the subsidiary's capabilities because of a lack of proper conditions at the location. Therefore, if extremely adverse conditions are present, the subsidiary will, as a consequence, barely evolve and will not gain better capabilities. Local barriers are also called Development Barriers in this work because six types of development barriers were identified for the subsidiary:

1. Market constraints concerns the lack of receptiveness to a company's products/services because of market issues, such as market decline, market maturation, different market needs, stiff competition, etc.

2. Supply constraints concerns the lack of availability of manufacturing inputs at the location, such as resources, raw materials, machinery, business services, availability of workers, etc.

3. Knowledge/technology constraints concerns the lack or limitations of, knowledge and technology at the location, such as skilled workers, skilled suppliers, advanced business practices among industrialists, qualified universities, etc.

4. Infrastructure constraints concerns the lack of the proper infrastructure at the location for running the business, such as highways, railroads, sea ports, airports, telephones, etc.

5. Legal constraints concerns the lack of a legal framework or the existence of an adverse one at the location, such as weak intellectual property protection, complex taxation systems and inflexible labor law.

6. Economic constraints concerns the availability of financial resources as well as economic stability at the location.

II. The Corporate (Optimization) Barrier is concerned with those milestones denoting that corporate coordination mechanisms constrain the development of a subsidiary's capability. This can be because it goes against the corporate strategy, it challenges the balance of the network or because it is simply affected by political decisions emerging from the balance of power in the organization. Therefore, if a subsidiary faces high corporate barriers it cannot optimize its operation and performance. Therefore, corporate barriers are also called Optimization Barriers in this work. In this case six optimization barriers have been identified:

1. Spare capacity is concerned with the allocation of resources and mandates in subsidiaries with substantially low capacity utilization that endangers its profitability and consequentially its existence.

2. Surplus prices regions for surplus cost regions is concerned with the allocation of resources and mandates in subsidiaries located in high cost regions allocated to supply countries or regions where the market is willing to pay surplus prices for high-priced products. 
3. Cost efficiency concerns the allocation of resources and mandates in subsidiaries established in lower cost manufacturing regions.

4. Inherited capabilities concerns the allocation of resources and mandates in subsidiaries holding a specific capability inherited from a former owner, historically authorized by HQ or as a result of the company's reward system.

5. Increasing interdependence concerns the allocation of resources and mandates in subsidiaries in order to increase interdependence among a network's nodes, with a consequential reduction in a specific node's influence across the corporate network and an improvement in network responsiveness.

6. Business Opportunities concerns the allocation of resources and mandates into new ventures emerging from business opportunities that temporarily limit the company's financial resources.

\section{Theorizing about Subsidiary Evolution Barriers}

It has been stated in this work that, during the localization process, a HQ conveys knowledge, transfers technology, facilitates learning processes and takes the plant/subsidiary to an initial desired role. Therefore, in theory no barriers should be present after a successful localization process. If development barriers are present, four possible issues may be emerging:

1. The location decision was made using inaccurate or incomplete knowledge.

2. The localization process was unsuccessful or incomplete.

3. There is low corporate awareness about changes in local business conditions.

4. The subsidiary is moving into a role not supported by the current location's advantages.

Even though the localization process should establish the subsidiary into an initial strategic role, HQ and subsidiary coordination is needed to ensure the corporation gets the best from that specific facility, since effective management of foreign subsidiaries will ensure not only the success of the plant or subsidiary but also increase the probability of maintaining business activities at the location (Cerrato, 2006). However, even under the tightest subsidiary control, not every single activity can be regulated and foreseen; an appeal to the entrepreneurship of local managers is needed to procure local opportunities that enhance the subsidiary's position and the consequential empowerment of the corporation. Hence, it is possible to obtain evidence of the above discussion in the case study: the parent's corporate strategy had a strong influence on the Mexican subsidiary's performance, either in developing more capabilities in the subsidiary or in discouraging local attempts to gain them.

According to the discussion above we can suggest that a subsidiary's ability to develop capabilities in addition to the ones that were first allocated to develop its initial plant or subsidiary role are constrained in different degrees by Development and Optimization barriers. Figure 2 shows the effect of the interaction between the Development and Optimization barriers on extended capabilities, which are grouped as Sourcing and $\mathbf{R} \boldsymbol{\&} \mathbf{D}$ and used as examples of more advanced capabilities in comparison to the ones considered basic to serial production of mature products such as production and logistics. In the sourcing group, every subsidiary in the corporate network contributes to the company's pool of suppliers even if Development and Optimization barriers are high; basically because Global Sourcing ${ }^{(1)}$ mechanisms are designed to find the world's best source, mainly in terms of price (Quadrant 1). 


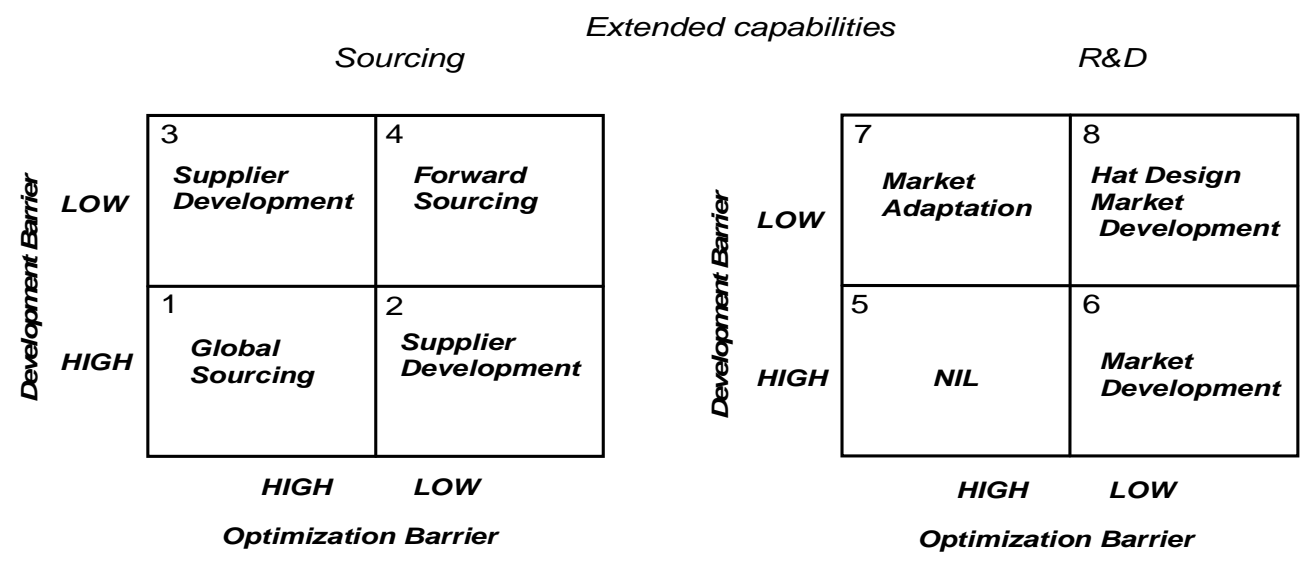

Figure 2. Effect of the Interaction between Development and Optimization Barriers on Extended Capabilities.

Consequently, if the subsidiary can overcome certain optimization barriers by getting HQ to support the move to a higher role, the next step in terms of sourcing would be to develop strategies with local manufacturers to achieve lower costs and enhanced services such as responsiveness and inventory reductions (Quadrant 2). It is expected that once a specific knowledge, technology or manufacturing practice has been implemented between the subsidiary and a supplier, it will generate a synergy among the subsidiary's pool of suppliers to replicate the success. Therefore, suppliers' development capability is needed to bring weaker suppliers along the value chain up to the necessary standard (Quadrant 3). The subsidiary in question provides an important example of how logistics practices such as Just in Time and Sequenced Delivering were implemented first with main suppliers and subsequently with others. Finally, a subsidiary will reach a mature stage in terms of sourcing once suppliers in its pool participate in the Forward Sourcing ${ }^{(2)}$ mechanism and start influencing the product development process of the company (Quadrant 4).

A slightly different situation exists in the R\&D group: if the Development and Optimization barriers are high, subsidiaries won't participate in any of the $R \& D$ activities. This is mainly the case for young subsidiaries that have not yet mastered basic functions (functions for serial production, such as production and logistics) and concentrate their efforts on accomplishing their initial role (Quadrant 5). However, as soon as the initial role is being accomplished, subsidiaries tend to become less dependent on HQ's in operational terms and therefore the consequential step is for them to develop their own market (Quadrant 6). It is important to mention that we consider the market development capability in an expanded way: from market information gathering to foreseeing opportunities and creating market niches from them.

The case study provided an important example of creating new market niches when it relaunched the Beetle for the Mexican market; however, no product development has been carried out by the subsidiary. If Development barriers have been gradually overcome, mainly by supplier development capability, as stated in the Source group, subsidiaries will partner with suppliers in order to adapt products for specific market needs. This is the case where subsidiaries export global products to markets where environmental and safety regulations are different, or to a greater extent, if particular customers' tastes have to be fulfilled (Quadrant 7). The last position on the chart is when a subsidiary is not only located in a frugal location but also enjoys a special freedom derived from low Optimization barriers. In consequence, subsidiaries will start to design products for their specific market needs, via market development and hat ${ }^{(3)}$ design capability (Quadrant 8 ). It is important to mention that due to the cost of product development in the automotive sector, it is very unlikely that a subsidiary would embark on designing a vehicle's platform since it is very costly; therefore, this activity is concentrated at $\mathrm{HQ}$. 
In order to conclude the previous discussion, it is useful to derive a typology of the subsidiary's position and its internationalization driver. Such a typology would summarize not only the position of a subsidiary in terms of its development but also help show the specific position where a parent company would be more likely to drive such a subsidiary, depending on its corporate strategy. Figure 3 shows the subsidiary and its internationalization drivers' typology, where Quadrant 1a states that the main rationale of a subsidiary in a location with high Development barriers and high Optimization barriers will be to target the local market. However, it is important to mention that the rationale of this type of subsidiary is different from the ones whose main purpose is to benefit from low manufacturing costs, since they will produce for a global reach based on a global product (Quadrant 2a). The difference in the degree of development barriers in the above-explained quadrants relies on the facilitation of mechanisms to export production volumes to other countries such as tax exemptions, flexibility of labor, creation of export processing zones, and the inclusion of the location in a free trade zone, among others. Therefore, recent established subsidiaries that spend time reaching the desired role and fighting against Development and Optimization barriers are called Green Nodes, Quadrant $1 b$; while subsidiaries exporting the greatest part of their production volumes behave like Hub Nodes in the network, Quadrant 2b.

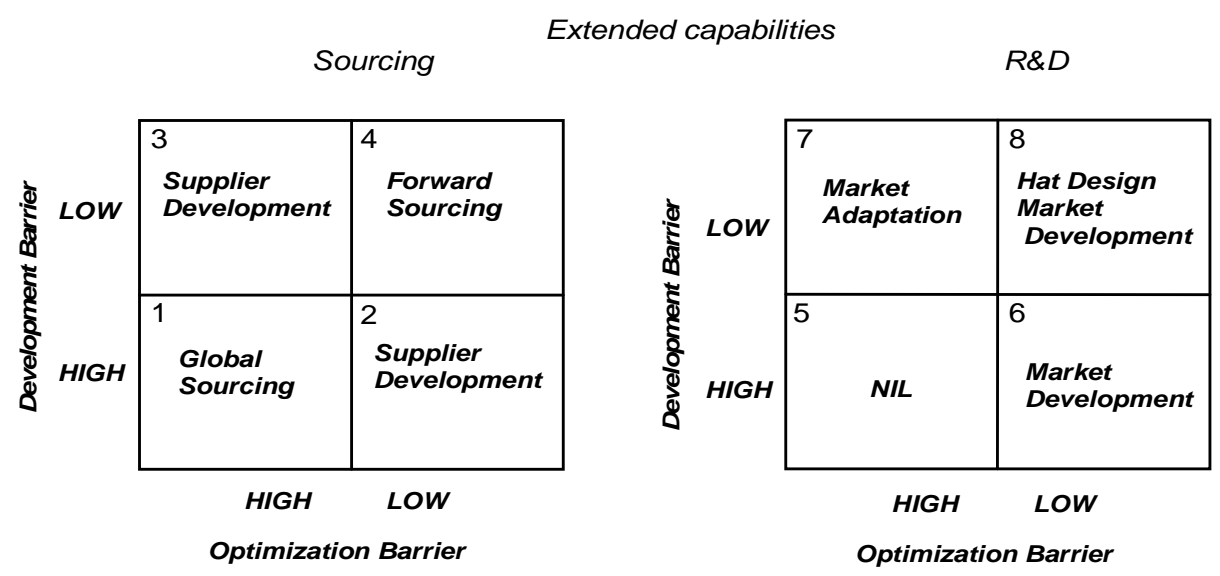

Figure 3. The Subsidiary and its Internationalization Driver Typology.

On the other hand, it is expected that a subsidiary would eventually overcome optimization and development barriers, develop further capabilities and move on to higher roles in the corporate network. Without this, the subsidiary will endanger its existence. This is the case for loss-making subsidiaries that, after a trial period, the parent company decides to divest. Sometimes, depending on the extent of the development barrier and the attitude of the company towards risk, subsidiaries are not divested but their activity is kept to the minimum in order to quickly react to potential business opportunities (Quadrant 3a).

The case study offers clear examples of this type of subsidiary since the company put investments on hold in several countries such as Russia and Colombia until better business conditions should appear; subsidiaries under these circumstances behave like Barren Nodes (Quadrant 3b). A subsidiary that has successfully overcome Development and Optimization barriers will embed itself in internal and external networks in order to empower its products and services (Quadrant 4a). These subsidiaries are recognized as centers of excellence within their networks and behave as Forceful Nodes (Quadrant 4b). Finally, it is important to mention that subsidiary positions among Quadrants are not fixed since a subsidiary that has become a Hub or Forceful Node could eventually fall into a Barren Node position if new development barriers emerge or they simply lose coherence with current corporate strategy. 


\section{Conclusions}

Evidence from the analysis of subsidiary localization processes suggests that subsidiaries' potential for success is reinforced if their corporations take them to a mature stage defined as Plant Role. In order to reach the mature stage, corporations need to invest heavily in education and training until subsidiaries are able to replicate corporate knowledge faithfully; this status is verified once subsidiaries' managers disengage operationally from $\mathrm{HQ}$ and the use of expatriates is kept to minimum.

The parent-subsidiary relationship suggests that subsidiaries' potential for success is conditioned by the definition of initial plant roles that reflect reliably what subsidiaries can offer to corporations rather than what corporations need from them. Local input is critically important for the definition of coherent plant roles and, rather than being a one-off exercise, these roles need to be monitored by subsidiary managers; feeding back any challenges, threats or trends to their corporate strategy.

The analysis of potential sources of corporate and location barriers would improve not only configuration and coordination mechanism but also increase fair competition across a corporate network, as well as give an opportunity to HQs to monitor host locations and adopt subsidiary strategic role accordingly.

The subsidiary's evolutionary process suggests that subsidiaries' potential for success is subject to having an official, committed and active process of subsidiary embeddedness in their corporate network and local/global business environment. This process will increase subsidiaries' interdependence with their related business framework, increasing the probability not only of keeping their rationale for existence but also pushing forward their plant roles to more advanced capability levels. Data alludes to the idea that that subsidiaries possessing highly mature stages become centers of excellence for their corporations, having the ability not only to faithfully deploy corporate knowledge but also being capable of collecting, codifying and packaging commercially exploitable knowledge that can be conveyed back to their head corporations.

\section{Artigo recebido em 12.10.2009. Aprovado em 15.09.2010.}

\section{Notes}

${ }^{1}$ Global sourcing is a procurement strategy to ensure the best worldwide source is introduced as supplier into the manufacturing network.

${ }^{2}$ Forward sourcing is a procurement strategy to lower the product development cost by partnering with the best suppliers.

${ }^{3}$ A passenger car's system is grouped into two main classifications: the platform composed of the engine, transmission, exhaust, etc.; and hat, which is composed of body work and all equipment inside it.

\section{References}

Almeida, P., \& Phene, A. (2004). Subsidiaries and knowledge creation: the influence of the mnc and host country on innovation. Strategic Management Journal, 25(8/9), 847-864. doi: $10.1002 / \mathrm{smj} .388$

Ambos, T., \& Birkinshaw, J. (2010). Headquarters' attention and its effect on subsidiary performance. Management International Review, 50(4), 449-469. doi: 10.1007/s11575-010-0041-4 
Andersson, U., \& Forsgren, M. (1996). Subsidiary embeddedness and control in the multinational corporation. International Business Review, 5(5), 487-508. doi: 10.1016/0969-5931(96)00023-6

Andersson, U., \& Forsgren, M. (2000). In search of centre of excellence: network embeddedness and subsidiary roles in multinational corporations. Management International Review, 40(4), 329$350 . \quad$ Retrieved from http://0search.ebscohost.com.millenium.itesm.mx/login.aspx?direct=true \&db=buh\&AN=12146143\&sit $\mathrm{e}=$ bsi-live

Andersson, U., Forsgren, M., \& Holm, U. (2001). Subsidiary embeddedness and competence development in MNCs a multi-level analysis. Organization Studies, 22(6), 1013-1034. doi: $10.1177 / 0170840601226005$

Andersson, U., Forsgren, M., \& Holm, U. (2002). The strategic impact of external networks: subsidiary performance and competence development in the multinational corporation. Strategic Management Journal, 23(11), 979-996. doi: 10.1002/smj.267

Andersson, U., Forsgren, M., \& Pedersen, T. (1999). The MNC as a differentiated network: subsidiary technology embeddedness and performance. Copenhagen Business School, Open Archives. $\begin{array}{llll}\text { Retrieved September } & 9, & \text { 2010, }\end{array}$ http://openarchive.cbs.dk/bitstream/handle/10398/6621/wp3.pdf?sequence=1

Bartlett, C., \& Ghoshal, S. (1987). Managing across borders: new strategic requirements. Sloan Management Review, 28(4), 7-17. Retrieved from http://0search.ebscohost.com.millenium.itesm.mx/login.aspx?direct=true \&db=buh\&AN=4021934\&site $=$ bsi-live

Beugelsdijk, S., Pedersen, T., \& Petersen, B. (2009). Is there a trend towards global value chain specialization? - An examination of cross border sales of US foreign affiliates. Journal of International Management, 15(2), 126-141. doi:10.1016/j.intman.2008.08.002

Birkinshaw, J. (1995). Encouraging entrepreneurial activity in multinational corporations. Business Horizons, 38(3), 32-38. Retrieved from http://0search.ebscohost.com.millenium.itesm.mx/login.aspx?direct=true \&db=buh\&AN=9506080165 $\&$ site $=$ bsi-live

Birkinshaw, J. (1996). How multinational subsidiary mandates are gained and lost. Journal of International Business Studies, 27(3), 467-495. doi:10.1057/palgrave.jibs.8490845

Cantwell, J., Dunning, J., \& Lundan, S. (2010). An evolutionary approach to understanding international business activity: the co-evolution of MNEs and the institutional environment. Journal of International Business Studies, 41(4), 567-586. doi:10.1057/jibs.2009.95

Cantwell, J., \& Mudambi, R. (2005). MNE competence-creating subsidiary mandates. Strategic Management Journal, 26(12), 1109-1128. doi: 10.1002/smj.497

Casson, M., Dark, K., \& Gulamhussen, M. (2009). Extending internalisation theory: from the multinational enterprise to the knowledge-based empire. International Business Review, 18(3), 236-256. doi:10.1016/j.ibusrev.2008.12.005

Cerrato, D. (2006). The multinational enterprise as an internal market system. International Business Review, 15(3), 253-277. doi:10.1016/j.ibusrev.2006.02.001

Clark, I., \& Almond, P. (2004). Dynamism and embeddedness: towards a lower road? British subsidiaries of American multinationals. Industrial Relations Journal, 35(6), 536-556. doi: 10.1111/j.1468-2338.2004.00332.x 
Criscuolo, P., \& Narula, R. (2007). Using multi-hub structures for international R\&D: organisational inertia and the challenges of implementation. Management International Review, 47(5), 639660. doi: 10.1007/s11575-007-0038-9

Davis, L., \& Meyer, K. (2004). Subsidiary research and development, and the local environment. International Business Review, 13(3), 359-382. doi:10.1016/j.ibusrev.2003.06.003

Eckert, S., \& Rossmeissl, F. (2007). Local heroes, regional champions or global mandates? Empirical evidence on the dynamics of German MNC subsidiary roles in Central Europe. Journal of EastWest Business, 13(2/3), 191-218. doi: 10.1300/J097v13n02_05

Falck, O., \& Heblich, S. (2008). Modern location factors in dynamic regions. European Planning Studies, 16(10), 1385-1403. doi: 10.1080/09654310802420094

Ferdows, K. (1997). Making the most of foreign factories. Harvard Business Review, 75(2), 73-88. doi: $10.1225 / 97204$

Gammelgaard, J. (2009). Issue selling and bargaining power in intrafirm competition: the differentiating impact of the subsidiary management composition. Competition \& Change, 13(3), 214-228. doi: 10.1179/102452909X451341

Garcia-Pont, C., Canales, J., \& Noboa, F. (2009). Subsidiary strategy: the embeddedness component. Journal of Management Studies, 46(2), 182-214. doi: 10.1111/j.1467-6486.2008.00797.x

Ghoshal, S., \& Bartlett, C. (1990). The multinational corporation as an interorganizational network. Academy of Management Review, 15(4), 603-625. doi: 10.2307/258684

Gupta, A., \& Govindarajan, V. (1991, August). Knowledge flow patterns, subsidiary strategic roles, and strategic control within MNCs. Proceedings of Academy of Management Best Papers, Chicago, IL, USA.

Holm, U., Malmberg, A., \& Sölvell, Ö. (2003). Subsidiary impact on host-country economies - the case of foreign-owned subsidiaries attracting investment into sweden. Journal of Economic Geography, 3(4), 389-408. doi: 10.1093/jeg/lbg014

Jarillo, J., \& Martínez, J. (1990). Different roles for subsidiaries: the case of multinational corporations in Spain. Strategic Management Journal, 11(7), 501-512. doi: 10.1002/smj.4250110702

Jenkins, M., \& Tallman, S. (2010). The shifting geography of competitive advantage: clusters, networks and firms. Journal of Economic Geography, 10(4), 599-618. doi: 10.1093/jeg/lbq015

Kang, E., \& Li, D. (2009). Understanding diverging isomorphic pressures on foreign subsidiary managers: a contingency model. Multinational Business Review, 17(1), 1-21. Retrieved from http://vlex.com/vid/diverging-isomorphic-pressures-contingency-204277871

Khurana, A., \& Talbot, B. (1998). The internationalization process model through the lens of the global color picture tube industry. Journal of Operations Management, 16(2/3), 215-239. doi:10.1016/S0272-6963(97)00039-9

Lall, S. (2002). FDI and development: research issues in the emerging context. In B. Bora (Ed.), Foreign Direct Investment: Research Issues (pp. 325-345). Routledge.

Li, J., \& Rugman, A. (2007). Real options and the theory of foreign direct investment. International Business Review, 16(6), 687-712. doi: 10.1016/j.ibusrev.2007.08.004

Luo, Y., \& Zhao, H. (2004). Corporate link and competitive strategy in multinational enterprises: a perspective from subsidiaries seeking host market penetration. Journal of International Management, 10(1), 77-105. doi: 10.1016/j.intman.2003.12.006 
Marin, D., \& Verdier, T. (2009). Power in the multinational corporation in industry equilibrium. Economic Theory, 38(3), 437-464. doi: 10.1007/s00199-007-0327-3

Maritan, C., Brush, T., \& Karnani, A. (2004). Plant roles and decision autonomy in multinational plant networks. Journal of Operations Management, 22(5), 489-503. doi: 10.1016/j.jom.2004.05.007

McDonald, F., Warhurst, S., \& Allen, M. (2008). Autonomy, embeddedness, and the performance of foreign owned subsidiaries. Multinational Business Review, 16(3), 73-92.

Nachum, L., Zaheer, S., \& Gross, S. (2008). Does it matter where countries are? Proximity to knowledge, markets and resources, and MNE location choices. Management Science, 54(7), 1252-1265. doi: $10.1287 / \mathrm{mnsc} .1080 .0865$

Narula, R., \& Dunning, J. (2000). Industrial development, globalization and multinational enterprises: new realities for developing countries. Oxford Development Studies, 28(2), 141-167. doi: $10.1080 / 713688313$

Ozawa, T., \& Castello, S. (2001). Toward an 'international business' paradigm of endogenous growth: multinationals and governments as co-endogenisers. International Journal of the Economics of Business, 8(2), 211-228. doi: 10.1080/13571510110051450

Papanastassiou, M., \& Pearce, R. (2005). Funding sources and the strategic roles of decentralised $\mathrm{R} \& \mathrm{D}$ in multinationals. $R \& D$ Management, $35(1), \quad 89-99$. doi: $10.1111 / \mathrm{j} .1467-$ 9310.2005.00374.x

Peneder, M. (2002). Intangible investment and human resources. Journal of Evolutionary Economics, 12(1/2), 107-134. doi: 10.1007/s00191-002-0103-2

Reger, G. (2004). Coordinating globally dispersed research centres of excellence - the case of Philips Electronics. Journal of International Management, 10(1), 51-76. doi: 10.1016/j.intman.2003.12.004

Salgado, O. (2008). Emerging capabilities in manufacturing companies: a new taxonomy of company's transformations. Saarbrücken: VDM Verlag Dr. Muller Aktiengesellschaft \& Co. KG.

Shi, Y., \& Gregory, M. (1998). International manufacturing networks - to develop global competitive capabilities. Journal of Operations Management, 16(2/3), 195-214. doi: 10.1016/S02726963(97)00038-7

Talay, M., \& Cavusgil, S. (2009). Choice of ownership mode in joint ventures: an event history analysis from the automotive industry. Industrial Marketing Management, 38(1), 71-82. doi: 10.1016/j.indmarman.2007.06.015

Tsai, M.-T., Yu, M.-C., \& Lee, K.-W. (2006). Relationships between subsidiary strategic roles and organizational configuration: the case of Taiwanese multinational companies. International Journal of Commerce \& Management, 16(1), 3-14. doi: 10.1108/10569210680000203

United Nations Conference on Trade and Development. (2010). Statistical databases online. Retrieved September 8, 2010, from http://www.unctad.org/Templates/Page.asp?intItemID=1888\&lang=1

Vereecke, A., \& Dierdonck, R. van (2002). The strategic role of the plant: testing ferdows's model. International Journal of Operations \& Production Management, 22(5), 492-514. doi: $10.1108 / 01443570210425147$ 